\title{
Hybrid electric powertrain for long-haul trucks and buses: preliminary analysis of a new concept based on a combined cycle power plant
}

\author{
Original article \\ Article history: \\ Accepted: 13 March 2020 \\ Published: 20 May 2020 \\ This is the updated version of a paper \\ originally presented at the Global Power \\ and Propulsion Technical Conference, \\ GPPS Montreal18, in Montreal, May 7-9 \\ 2018.
}

\section{Check for updates}

\section{*Correspondence:}

PC: p.colonna@tudelft.nl

\section{Peer review:}

Single blind

\section{Copyright:}

(C) 2020 Bahamonde Sebastián et al. @) This is an open access article distributed under the Creative Commons Attribution License (CC-BY 4.0), which permits unrestricted use, distribution, and reproduction in any medium, provided the original work is properly cited and its authors credited.

\section{Keywords:}

organic Rankine cycle; combined cycle; truck; Hybrid Electric Vehicle (HEV): powertrain

\section{Citation:}

Bahamonde S., de Servi C., and Colonna P. (2020). Hybrid electric powertrain for longhaul trucks and buses: preliminary analysis of a new concept based on a combined cycle power plant. Journal of the Global Power and Propulsion Society. 4: 63-79. https://doi.org/10.33737/jgpps/118979

\author{
Sebastián Bahamonde ${ }^{1}$, Carlo de Servi ${ }^{2}$, Piero Colonna ${ }^{1, *}$ \\ ${ }^{1}$ Propulsion and Power, Delft University of Technology, Delft, South Holland, The Netherlands \\ ${ }^{2}$ Energy Technology, Flemish Institute for Technological Research (VITO), Mol, Antwerp, Belgium
}

\begin{abstract}
The electric hybridization of heavy-duty road vehicles is a promising alternative to reduce the environmental impact of freight and passengers transportation. Employing a micro gas turbine as a prime mover offers several advantages: high power density, fuel flexibility, ultra-low emissions (without the need of exhaust after-treatment), low vibrations and noise, simplicity and lower maintenance cost. State-of-the-art micro gas turbines feature an efficiency of $30 \%$, which can be increased to $40 \%$ by employing a mini organic Rankine cycle system as a bottoming power plant. Such a combined-cycle powertrain could achieve considerably higher efficiency with next-gen micro gas turbines and mini ORC systems, especially with an R\&D push of the automotive sector. This paper presents the analysis of a hybrid electric heavy-duty vehicle with a prime mover based on this concept.
\end{abstract}

The assessment was performed in two steps: (i) preliminary design of the combined cycle power plant, and (ii) estimation of the vehicle fuel economy and of the emissions over a representative driving cycle. The best combined cycle system stemming from the design exercise features an estimated peak efficiency of $44 \%$, and a nominal power output of about $150 \mathrm{~kW}$. This corresponds to the power demand at cruise condition of a long-haul truck (weight approx. 36 ton). A series configuration with Lithium-Ion batteries was selected for the hybrid powertrain, for it decouples the prime mover dynamics from the power demand. The benchmark is a vehicle featuring a next generation diesel engine, with a peak efficiency equal to $50 \%$.

The results show that the fuel economy can be largely improved by increasing the size of the battery in the hybrid powertrain. Furthermore, employing natural gas in the prime mover of the hybrid vehicle leads to ultra-low emissions that are well below the limits set by European and north American regulations, without the need of exhaust gas aftertreatment. Additionally, the $\mathrm{CO}_{2}$ emissions of the hybrid powertrain are considerably lower than that of the benchmark. The work documented here thus demonstrates the potential of this hybrid powertrain concept, especially in terms of exhaust emissions, as a promising transition technology towards the full electrification of the powertrain.

\section{Introduction}

Heavy-duty road transport produces approximately $5 \%$ of the European Union's total greenhouse gas emissions, contributing more than international shipping and aviation to the total $\mathrm{CO}_{2}$ release in the 
atmosphere (European Commission, Climate Action, 2017). Many organizations around the planet are investigating potential mitigation strategies, which arguably feature two main trends. The first one focuses on the improvement of the components in conventional reciprocating engines, e.g., design optimization of pistons for higher compression ratios (Gibble and Amar, 2016). The second trend instead aims at the electric hybridization of the power train. This configuration makes it possible to downsize the combustion engine, to recover energy during deceleration, to continuously operate the engine under optimal conditions, and to eliminate idle fuel consumption and clutching losses (Guzzella and Sciarretta, 2013). A hybrid electric power train is particularly suited for long-haul trucks (class 8 , weight $>15$ ton) and buses. These trucks travel for long distances, their current autonomy range cannot arguably be reached by means of a fully electric power train without significant payload penalties, due to the insufficient energy density of current and near-future electric batteries (Aharon and Kuperman, 2011). Furthermore, these vehicles operate in stable cruise conditions for many hours, hence the power plant and its control can be optimized for constant on-design operation allowing for higher efficiency and lower emissions. Several companies have been and are developing heavy-duty hybrid power trains with prime movers like reciprocating engines (Daimler Trucks North America LLC, 2017), fuel cells (Goodarzi, 2017), and micro gas turbines (Wrightspeed Powertrains, 2017).

The use of a gas turbine for road propulsion provides several potential merits: high power density, fuel flexibility, ultra-low emissions, low vibrations and noise, simplicity and lower maintenance cost. This concept was already studied decades ago. Even though commercial organizations realized prototypes of heavy-duty trucks and passenger cars, gas turbine powered vehicles were not introduced into the market, mainly due to the poor efficiency of micro/ mini gas turbines, especially in off-design conditions (Chrysler Corporation: Technical Information Engineering office, 1979). This problem does not occur if the gas turbine is part of a hybrid system, because the machine can always run at optimal conditions independently from the vehicle speed and gear position. By employing a bottoming organic Rankine cycle (ORC) system, it is possible to increase the efficiency of micro gas turbines ( $\mu \mathrm{GT}$, power output $<500 \mathrm{~kW}$ ) to at least $40 \%$ (Invernizzi et al., 2007). Moreover, recovering waste energy from a single hightemperature source, the exhaust of a $\mu \mathrm{GT}$, is easier than recovering heat from a Diesel engine, for which the full recovery potential can only be achieved if also the low-temperature energy content of the cooling and lubrication system is employed.

This paper showcases the analysis of a hybrid power train for a class 8 truck employing a combined cycle with a $\mu \mathrm{GT}$ and a mini ORC system $(m \mathrm{ORC}$, power output $<50 \mathrm{~kW})$ as the prime mover. In this explorative investigation, the design of the ORC system components follow procedures corresponding to current and commercial technology levels. The results of this work are therefore conservative.

The assessment of the proposed power train concept was developed in two steps. The first step deals with the preliminary design of the combined cycle (CC) power plant, while the second focuses on the evaluation of the vehicle fuel economy over a representative mission. During the preliminary design phase, recuperative and nonrecuperative cycle configurations were studied, and the working fluids for the $m \mathrm{ORC}$ were selected by taking into account performance, manufacturing constraints typical of small scale turbomachinery, safety and environmental aspects. The design of the heat exchangers was performed with a well-known engineering software (Aspen Technology, Inc., 2015), and by taking into account constraints on weight and volume given by the vehicle architecture. The estimated characteristics of the CC gen-set are then used for the assessment of the fuel economy of a hybrid electric long-haul truck at full load (approx. 36 ton of weight); this analysis is performed with an open source library for quasi-steady-state simulations of road transport driving cycles (Guzzella and Ambühl, 2005). A series configuration with Lithium-Ion batteries was selected for the hybrid powertrain, because it decouples the prime mover dynamics from that of the vehicle (Guzzella and Sciarretta, 2013).

The objective of the analysis is to evaluate the trade-off between the size of the batteries and the cargo weight and fuel economy, and also to estimate the flue gas emissions if natural gas is employed.

\section{Methodology}

The preliminary design of the CC system has been carried out by means of a computer code developed with a general-purpose open source programming language (Python Software Foundation, 2017), while the evaluation of the fuel performance over selected driving cycles has been performed with an open-source library (QSS-Toolbox) (Guzzella and Ambühl, 2005), for use with a graphical programming environment for modeling, simulating and analyzing multidomain dynamical systems (The Mathworks, Inc., 2017). The estimation of fluid thermophysical properties needed for the thermodynamic cycle analysis of the considered CC systems are obtained by means of well-known fluid property libraries (Colonna et al., 2019; Bell et al., 2014). 


\section{Preliminary design of the combined cycle}

Figure 1 displays the three simplified schemes of the studied cycle configurations. The configuration of Figure 1a, named RGT-ORC, is based on a state-of-the-art $\mu \mathrm{GT}$ turbine operating with a low pressure ratio of four, a maximum turbine inlet temperature approaching $1000^{\circ} \mathrm{C}$, and a gas-to-gas recuperator with a maximum inlet temperature of approximately $650^{\circ} \mathrm{C}$ (Visser et al., 2011). Regarding the ORC system, a preliminary thermodynamic analysis showed that regeneration has little effect on the overall efficiency; the ORC regenerator is thus omitted. Additionally, the water in the flue gas might partially condense in the primary heat exchanger of the ORC unit. This phenomenon has been modeled following the procedure reported by Lu et al. (1987).

The CC power plant configuration in Figure $1 \mathrm{~b}$ is based on a non-recuperative gas turbine (GT-RORC). In this case, if a high thermodynamic efficiency is sought for, the turbine inlet temperature is to be raised at levels beyond those attainable by uncooled blades. An alternative is to employ a ceramic turbine, and this technology was demonstrated in the past with a TIT as high as $1350^{\circ} \mathrm{C}$ (McDonald and Rodgers, 2008). The potential of this technology is still under scrutiny, as shown by recent research projects on micro ceramic gas turbines for unmanned air vehicles (Vick et al., 2016). For this cycle configuration, the preliminary thermodynamic analysis showed that the best performance is achieved with a regenerator in the waste heat recovery system.

Figure 1c shows the third considered configuration (GT- RLORC), a non-recuperative gas turbine with a bottoming cycle employing an additional (low temperature) heat recovery exchanger (LTHRE). In this case, the liquid flow leaving the ORC pump is split, in order to obtain an optimal match between the temperature profiles of the hot and cold stream in the regenerator. The bypassed liquid flow is then preheated by the exhaust gases after exiting the high-temperature heat recovery exchanger (HTHRE), thus increasing the amount of thermal energy that is utilized. Also this system requires a high gas turbine inlet temperature, in order to reach a high conversion efficiency. Here, instead of a ceramic turbine, film blade cooling is considered (Taguchi et al., 2017). It could be then possible to raise the turbine inlet temperature to values as high as $1500^{\circ} \mathrm{C}$ (like in modern stationary gas turbines or aero engines). The impact of film cooling on the thermodynamic cycle efficiency is taken into account by following the work of Horlock (2003), and assuming a four stage machine with cooling at the inlet of the first two stages.

A thermodynamic cycle analysis is used to determine the optimal cycle specifications, which are then used to design the turbomachinery and the heat exchangers. The procedure can be consulted in any engineering Thermodynamics textbook, see, e.g., Reynolds and Colonna (2018); thus, it is not reported here. A degree of freedom of these CC configurations is the ORC condensing temperature. Its value is determined following the calculation procedure described in the following section.

\section{Determination of the ORC condensing temperature}

The geometry of the ORC condenser is assumed of the plate-fin and tube type, like that of ICE radiators, with louvered-fins in the air side, and single-pass flat tubes in the working fluid side, see Figure 2a.

The condenser is installed on the front of the vehicle and its size is taken equal to that of a typical radiator on board of long-haul trucks. The aerodynamic performance of the truck configurations is considered the same. In order to obtain the condensing temperature, the thermodynamic cycle analysis of the candidate CC configurations is simulated with condensing temperatures varying between $50^{\circ} \mathrm{C}$ and $80^{\circ} \mathrm{C}$. This allows to estimate the condenser operating conditions (working fluid mass flow rate, and inlet/outlet thermodynamic states) which are

a

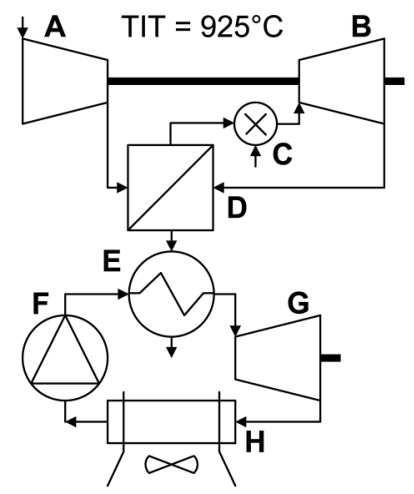

b

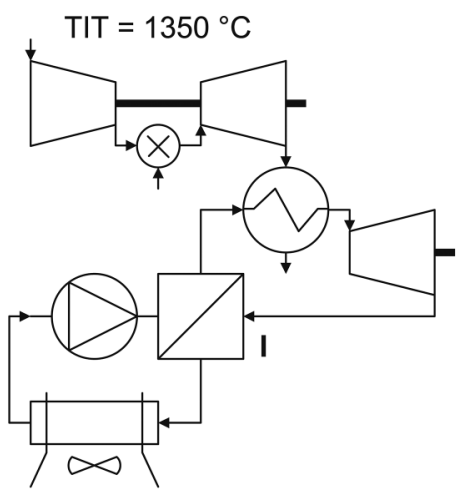

C

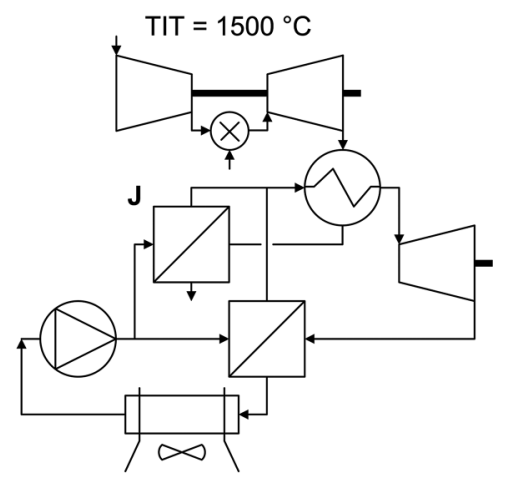

A: compressor B: gas turbine C: combustor D: recuperator E: HTHRE F: pump G: ORC turbine $\mathrm{H}$ : condenser l: regenerator J: LTHRE

Figure 1. Process flow diagrams of the studied combined cycle systems. (a) RGT-ORC, (b) GT-RORC, (c) GT-RLORC. 
a

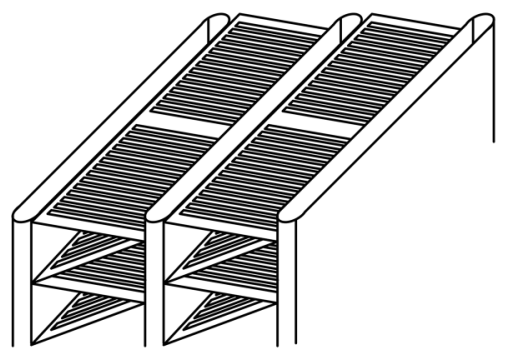

b

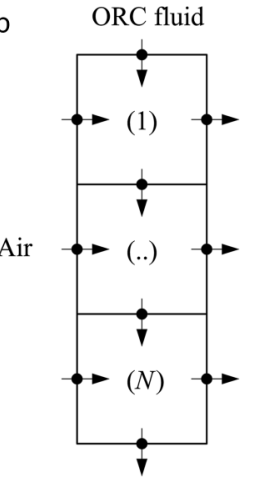

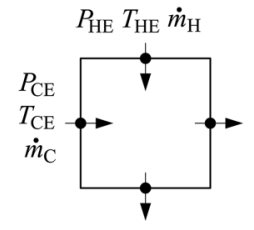

Figure 2. (a) Louver fin with triangular channel, adapted from Chang and Wang, 1997. (b) Scheme of the onedimensional discretization.

required as inputs to a rating model of the heat exchanger. The model outputs are the required air mass flow rate and the corresponding pressure drop. The condensing temperature is then the minimum value whereby the calculated pressure loss is equal to the dynamic pressure of the air stream entering the radiator at cruise speed, thus guaranteeing that the radiator can operate solely with RAM air.

The rating model of the condenser is based on a one-dimensional discretization of the geometry, as illustrated in Figure 2b.

Mass, energy and momentum balances are evaluated for each cell. Details of the solution strategy can be consulted in the book of Shah and Sekulić (2003). The overall heat transfer coefficient, assuming negligible fouling, reads

$$
\frac{1}{U A}=\frac{1}{\left(\eta_{f} \chi A\right)_{\mathrm{H}}}+R_{\mathrm{W}}+\frac{1}{\left(\eta_{f} \chi A\right)_{\mathrm{C}}}
$$

where $\eta_{f}$ is the fin efficiency, $\chi$ is the fluid heat transfer coefficient, $A$ is the heat transfer area, and $R_{\mathrm{W}}$ is the wall resistance. The subscripts $\mathrm{H}$ and $\mathrm{C}$ indicate the hot and cold sides of the heat exchanger, respectively.

Following the various assumptions listed by Shah and Sekulić (ibid.), and neglecting the momentum effect, the hot and cold side single-phase pressure drop are computed as

$$
\Delta P=\frac{G^{2}}{2}\left[\frac{1-\sigma^{2}+K_{\mathrm{i}}}{\rho_{\mathrm{i}}}+f \frac{L}{\eta_{\mathrm{h}}} \rho_{\mathrm{i}} \frac{1}{2}\left(\frac{1}{\rho_{\mathrm{i}}}+\frac{1}{\rho_{\mathrm{o}}}\right)-\frac{1-\sigma^{2}+K_{\mathrm{o}}}{\rho_{\mathrm{o}}}\right]
$$

where $G$ is the mass flux, $\rho_{\mathrm{i}}$ is the inlet density, $\rho_{\mathrm{o}}$ is the outlet density, $f$ is the Fanning friction factor, $\sigma$ is the ratio of core minimum free-flow area to frontal area. $K_{\mathrm{i}}$ and $K_{\mathrm{o}}$ are entrance and exit pressure loss coefficients defined by Kays and London (1998). Their values have been computed assuming a multiple-tube flat-tube core on the hot side, and a multiple triangular tube core on the cold side.

The correlations for the Colburn and Fanning friction factor of the air side are those for a louvered fin geometry developed by Chang and Wang (1997) and Chang et al. (2000). For the hot side, the Nusselt number and Fanning friction factor are computed with the correlations for flat tubes developed by Spiga and Dall'Olio (1995) under laminar flow conditions, while the correlations of Gnielinski (1976) are used in case of turbulent regime. According to the recommendation of Hesselgreaves (2001), the heat transfer coefficient for a condensing flow is computed with the multiplication factor introduced by Taylor (1990). The two-phase friction factor coefficient is obtained with the method of Lockart and Martinelli (1949). The fin efficiency for the air side is that of a louver fin (Shah and Sekulić, 2003). Finally, the wall resistance (flat tube wall) is computed assuming a flat plate geometry.

The implementation of the condenser design method has been successfully validated by comparison with cases documented in the article of Yadav et al. (2017).

\section{Turbomachinery meanline design}

The thermodynamic cycle analysis provides the inputs for the design of the turbines. This task is performed with an in-house meanline code (Pini et al., 2013; Asimptote, 2017). The loss models implemented in this software 
are listed in the work of Bahamonde et al. (2017). The program has been validated with conventional test cases, i.e., turbines operating with ideal-gas fluids, large Reynolds numbers, and subsonic flows. Efforts are currently underway to perform the validation of the code using $m$ ORC machine cases (Head et al., 2016; Pini et al., 2017). Being this work a first exploratory investigation, the design of compressors and pumps, and the effect of blade film cooling on the turbine efficiency is left for future studies.

\section{Preliminary design of the heat exchangers}

Plate-fin exchangers are selected, because they are a mature technology that has been widely used in industry for decades, including the automotive and aerospace sectors. Their manufacturing process allows for the use of different metals that can operate with temperatures of up to $840^{\circ} \mathrm{C}$, which can be increased to $1150^{\circ} \mathrm{C}$ by employing ceramic materials (Shah and Sekulić, 2003). Besides, plate-fin heat exchangers were selected for several prototypes of high temperature ceramic $\mu \mathrm{GT}$ power plants (McDonald and Rodgers, 2008). A commercial software is employed for their design (Aspen Technology, Inc., 2015).

The weight of the CC system is an input for the analysis of the fuel economy. As a first approximation, this is taken equal to the weight of the heat exchangers.

\section{Analysis of the fuel economy for a heavy-duty truck}

Figure 3 presents a flowchart of the quasi-steady-state models developed for the study of the two long-haul truck configurations considered here: $3 \mathrm{a}$ ) a conventional vehicle (CV) powered by a Diesel reciprocating engine, and $3 \mathrm{~b})$ a hybrid-electric vehicle (HEV). For a detailed explanation on how to model and simulate hybrid and nonhybrid vehicles the reader is referred to the work of Guzzella and Sciarretta (2013).

In order to analyze the $\mathrm{CV}$, components from the library have been modified to obtain two new models: a heavy-duty gearbox for the transmission, and a $320 \mathrm{~kW}$ reciprocating engine with its corresponding performance map. The required information has been obtained from an open-source database (Alliance for Sustainable Energy LLC, 2016), and it corresponds to a Kenworth T800 truck powered by a Caterpillar C15 engine.

The powertrain configuration selected for the HEV is of the series type, because this configuration allows to operate the gas turbine and the ORC system always under optimal conditions independently from the power demand. For this simulation, several model modules have been modified to include the following components:

- a lithium-ion battery, whose charge/discharge curves are obtained from a commercial manufacturer (Saft Batteries, 2005). The specific weight and power have been adjusted, to reflect recent estimations on the characteristics of state-of-art batteries for automotive applications (Bower, 2017).

- A $320 \mathrm{~kW}$ electric motor/inverter, whose performance maps have been obtained by linearly scaling those from a $220 \mathrm{~kW}$ machine (UQM Technologies, Inc., 2017). The regenerative braking power is computed by mirroring the torque-rotational speed efficiency map.

- The CC power plant. The start-up and the shut-down of the CC unit is controlled based on the state-ofcharge of the batteries. For simplicity, the start-up time and the corresponding energy consumption are not considered in the calculation of the HEV fuel economy.

The fuel economy or trucking efficiency is measured in ton-cargo.km $/ \mathrm{kg}$-fuel. This unit takes into account the payload, thus it is a more appropriate figure of merit for comparing the performance of different truck
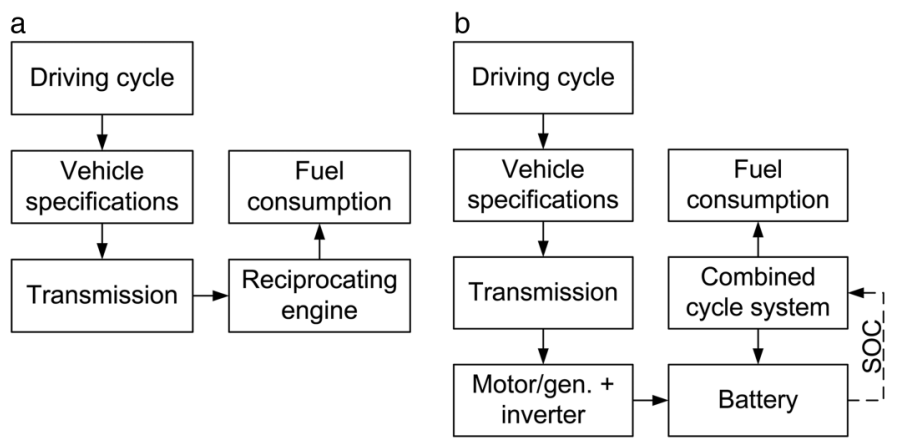

Figure 3. (a) Flowchart of the quasi-steady-state model of (a) a vehicle propelled by a conventional Diesel reciprocating engine, and (b) a series hybrid electric vehicle propelled by the proposed combined cycle system. 
configurations than the specific fuel consumption per km driven (Sharpe and Muncrief, 2015). Moreover, as a first approximation, it is assumed that the energy required to charge the batteries comes from power plants converting renewable energy sources, with negligible emissions and zero fossil-fuel consumption.

\section{HEV control strategy}

For missions characterized by long periods at constant speed, a on/off control strategy of the generator is appropriate (Ehsani et al., 2004). The CC system is thus started or stopped if the battery state-of-charge exceeds predefined limits: $90 \%$ for the shut-down and 10\% for the start-up. To calculate the fuel consumption of the HEV, it is assumed that the battery is discharged in a single cycle and the state-of-charge reaches $10 \%$ when the driving mission ends. Furthermore, the combined cycle power plant operates only when the truck is cruising. It follows that the ram air is always sufficient for the condensation of the working fluid of the ORC system, thus no fan is required.

As a first approximation, the energy consumption related to power plant start-up and shut-down is neglected. Such approximation has arguably no effect on the results of this work, because the driving cycle lasts hours, while the start-up/shut-down operations last minutes (De Paepe et al., 2014).

\section{Estimation of the emissions}

The HEV emissions are approximated assuming that the turbine operates with natural gas. However, gas turbines running on diesel and achieving very low emission levels are also available (Capstone Turbine Corp., 2010b). As far as CO, HC, NOx, and PM (particular matter) emissions are concerned, estimations are based on tests made by a commercial manufacturer on a $30 \mathrm{~kW}$ machine (Capstone Turbine Corp., 2010a). Coefficients are kept constant for the simulation of the entire driving cycle, because the gas turbine is assumed to operate always at design conditions, thus neglecting the start-up and shut-down phases. The emissions per unit energy are then compared against the current limits for heavy-duty vehicles prescribed by the United States Environmental Protection Agency (EPA) (Hoekman and Robbins, 2012), and by the European Union standards (EUROVI) (Reşitoğlu et al., 2015).

The $\mathrm{CO}_{2}$ emissions from the HEV can be computed by using the flue gas composition listed in Table 1 . The $\mathrm{CO}_{2}$ discharge from the conventional vehicle is computed assuming an average chemical formula for diesel, namely $\mathrm{C}_{12} \mathrm{H}_{24}$ (Date, 2011).

\section{Application and results}

\section{Preliminary design of the combined cycle}

Table 1 enumerates the model parameters considered for the thermodynamic cycle analysis. The CC nominal power output is taken equal to the mechanical power required at cruise conditions, as suggested by Ehsani et al. (2004). For a fully loaded long-haul truck (weight circa 36 tones, according to the limits in the U.S. roadways), trial computations showed that this power is approximately $150 \mathrm{~kW}$.

As far as the $\mu \mathrm{GT}$ model is concerned, the mechanical and combustor efficiency, the Brayton cycle pressure loss, and the recuperator effectiveness are taken from the work of Visser et al. (2011). The total Brayton cycle pressure loss is taken as a fraction of the maximum cycle pressure. The pressure losses are attributed to the various components according to Ref. (ibid.).

The Brayton cycle maximum temperature varies according to the CC-genset configuration under study: (a) the TIT of the gas turbine of the RGT-ORC configuration is set to $925^{\circ} \mathrm{C}$. Higher values would result in temperatures of the hot side inlet of the gas turbine recuperator exceeding the limit of $650^{\circ} \mathrm{C}$; (b) The TIT of the gas turbine of the GT-RORC configuration is set to $1350^{\circ} \mathrm{C}$, which corresponds to the maximum temperature arguably achievable in ceramic turbines; (c) The TIT of the gas turbine of the GT-RLORC configuration is set to $1500^{\circ} \mathrm{C}$, which is a feasible value for modern gas turbines with blade cooling. The turbine and compressor polytropic efficiencies are taken from the work of Massardo et al. (2002).

The selection of the ORC working fluid for the GT-RORC and GT-RLORC configurations was performed according to the considerations described in the following. As shown in the Application and Results Section (Figure 5), these power plants feature a gas turbine outlet temperature higher than $600^{\circ} \mathrm{C}$. It is thus desirable to select an organic fluid with high thermal stability, in order to minimize the thermodynamic losses associated with heat transfer in the HTHRE. Toluene arguably provides the best performance: it can operate at temperatures as high as $400^{\circ} \mathrm{C}$ (Invernizzi et al., 2017), and it leads to a comparatively high 
Table 1. Parameters for the thermodynamic cycle analysis.

\begin{tabular}{|c|c|c|}
\hline \multicolumn{3}{|l|}{ General parameters } \\
\hline Net power output & $\mathrm{kW}$ & 150 \\
\hline Environmental pressure & Bar & 1.01 \\
\hline Environmental temperature & ${ }^{\circ} \mathrm{C}$ & 15 \\
\hline Mechanical (bearing) efficiency & - & 0.98 \\
\hline \multicolumn{3}{|l|}{ Brayton cycle } \\
\hline Combustor efficiency & - & 0.999 \\
\hline Air composition & - & $\begin{array}{l}\mathrm{N}_{2}(0.7729) \mathrm{H}_{2} \mathrm{O}(0.0101) \operatorname{Ar}(0.0092) \mathrm{CO}_{2}(0.0003) \\
\mathrm{O}_{2}(0.2075)\end{array}$ \\
\hline Flue gas composition & - & $\mathrm{N}_{2}(0.7049) \mathrm{H}_{2} \mathrm{O}(0.1919) \operatorname{Ar}(0.0082) \mathrm{CO}_{2}(0.095)$ \\
\hline Maximum temperature & ${ }^{\circ} \mathrm{C}$ & $925^{a} / 1350^{b} / 1500^{c}$ \\
\hline Turbine polytropic efficiency & - & 0.84 \\
\hline Compressor polytropic efficiency & - & 0.79 \\
\hline Recuperator effectiveness & - & 0.87 \\
\hline Total pressure loss & - & 0.05 \\
\hline \multicolumn{3}{|l|}{ Rankine cycle } \\
\hline Working fluid & - & cyclopentane $^{a} /$ toluene $^{\mathrm{b}, \mathrm{c}}$ \\
\hline Maximum temperature & ${ }^{\circ} \mathrm{C}$ & $255^{a} / 400^{b, c}$ \\
\hline Turbine isentropic efficiency & - & 0.80 \\
\hline Pump isentropic efficiency & - & 0.60 \\
\hline Regenerator pinch & K & 20 \\
\hline P. loss, regeneration and evaporation & - & 0.01 \\
\hline $\begin{array}{l}\text { P. loss, regeneration and } \\
\text { condensation }\end{array}$ & - & 0.1 \\
\hline Maximum reduced evaporating P. & Bar & 1.1 \\
\hline Turbine max. vol. expansion ratio & - & 60 \\
\hline
\end{tabular}

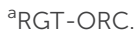

${ }^{\mathrm{b}} \mathrm{GT}$-RORC.

'GT-RLORC.

thermodynamic cycle efficiency, for it features a low molecular complexity (Invernizzi et al., 2007). As far as the RGT-ORC configuration is concerned, systems employing various working fluids were simulated. Ultimately, cyclopentane allowed to achieve the best simulated system performance, likewise due to its low molecular complexity. In case of cyclopentane, a maximum fluid operating temperature of $255^{\circ} \mathrm{C}$ has been prescribed. This value is lower than the thermal stability limit in contact with stainless steel that is 
mentioned in the literature (Invernizzi et al., 2017), because a safety margin should be considered given the level of uncertainty.

The values of the ORC model parameters follows common practice for such systems, see, e.g., Bahamonde et al. (2017) and Head et al. (2016). In particular, note that the maximum reduced evaporating pressure is set to 1.1, because larger values have little effect on the cycle thermodynamic efficiency. Moreover, the maximum turbine volumetric expansion ratio is 60 . Although such a value my seem too large for a single-stage RIT, the operation of commercial high-temperature $150 \mathrm{~kW}$ ORC turbines (Harinck et al., 2013), and a detailed recent numerical study, describing the design of a $10 \mathrm{~kW}$ ORC radial inflow expander, supports this assumption (Pini et al., 2017).

\section{ORC condensing temperature}

The length, width, and depth of the plate-fin condenser correspond to those of the radiator installed on a KentWorth T800 heavy-duty truck (Autozone, Inc., 2017). The louvered fin and plate geometric patterns are obtained from the work of Yadav et al. (2017).

Figure 4 presents the results of the condenser rating model for several condensing temperatures between $50^{\circ} \mathrm{C}$ and $80^{\circ} \mathrm{C}$, and using the parameters introduced in Table 1 . The combined cycle performance has been optimized by tuning the maximum cycle pressure of both the $\mu \mathrm{GT}$ and $m \mathrm{ORC}$ unit. The condensing temperature is that whereby the air side pressure drop is lower than the air dynamic pressure for a cruising speed of $85 \mathrm{~km} / \mathrm{h}$. Thus, see Figure 4, the condensing temperature values for each cycle configuration are: $80^{\circ} \mathrm{C}$ for RGT-ORC, $60^{\circ} \mathrm{C}$ for GT-RORC, and $70^{\circ} \mathrm{C}$ for GT-RLORC. These values may seem high. However, truck radiators operate with water at approximately $85^{\circ} \mathrm{C}$. This analysis has been done assuming an environmental temperature of $15^{\circ} \mathrm{C}$. Future work should consider the effects of ambient conditions (e.g., higher temperature values) and possibly other solutions and further optimization, as a lower condensing temperature considerably increases the efficiency of the power plant.

\section{Thermodynamic cycle analysis}

Figure 5a shows the efficiency of three CC configurations under scrutiny as a function of the Brayton cycle maximum pressure, assuming the condensing temperatures indicated in the previous paragraph; Table 2 lists cycle specifications for the thermodynamic cycles providing the highest performance, while Figure 6 shows the corresponding temperature-entropy diagrams.

Figure 5 shows that the GT-RLORC system allows to obtain the highest estimated conversion efficiency. This is due to a combination of two factors: the large difference between maximum and minimum temperature of the thermodynamic cycle $\left(1500^{\circ} \mathrm{C}\right.$ and $\left.70^{\circ} \mathrm{C}\right)$; and the higher efficiency of the bottoming cycle, due to the larger amount of thermal energy harvested from the GT exhaust gases. The $m$ ORC units of the GT-RORC and GTRLORC systems feature considerably higher thermal efficiency if compared to those from other ORC units designed for automotive waste heat recovery, see e.g., (Shi et al., 2018). This is a result of the high gas turbine exhaust temperature (approx. $800^{\circ} \mathrm{C}$ ), which allows raising the ORC turbine inlet temperature to a very high value, namely $400^{\circ} \mathrm{C}$.

Despite the fact that the GT-RORC and GT-RLORC systems feature the best predicted thermal efficiencies, these configurations are suboptimal, because of the considerable exergy destruction affecting the heat recovery exchanger, see

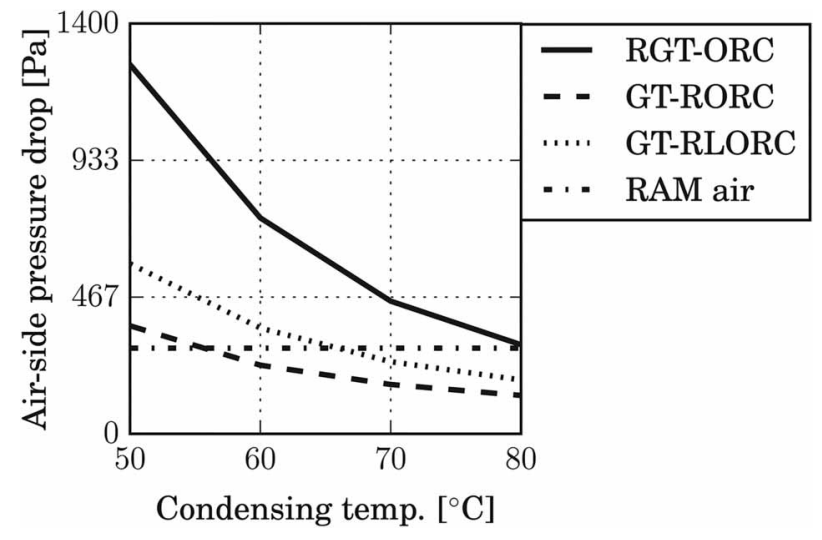

Figure 4. Radiator airside pressure drop as a function of the condensing temperature. 


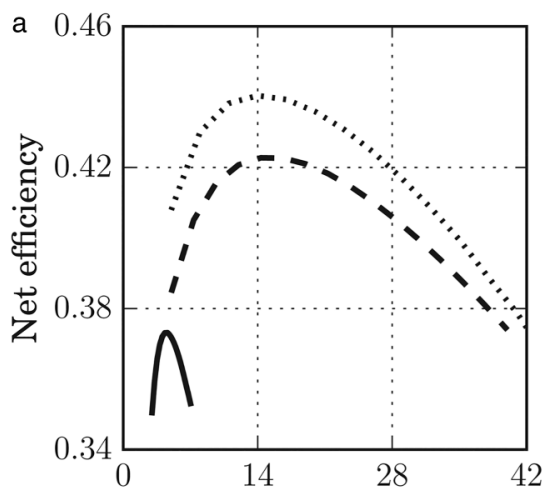

Brayton cyc. max press. [bar]

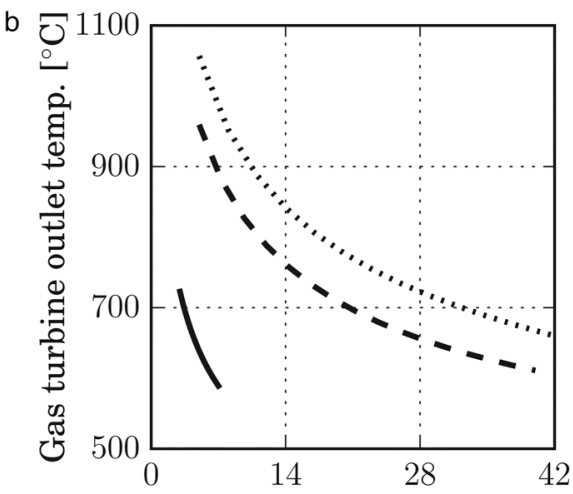

Brayton cyc. max press. [bar]

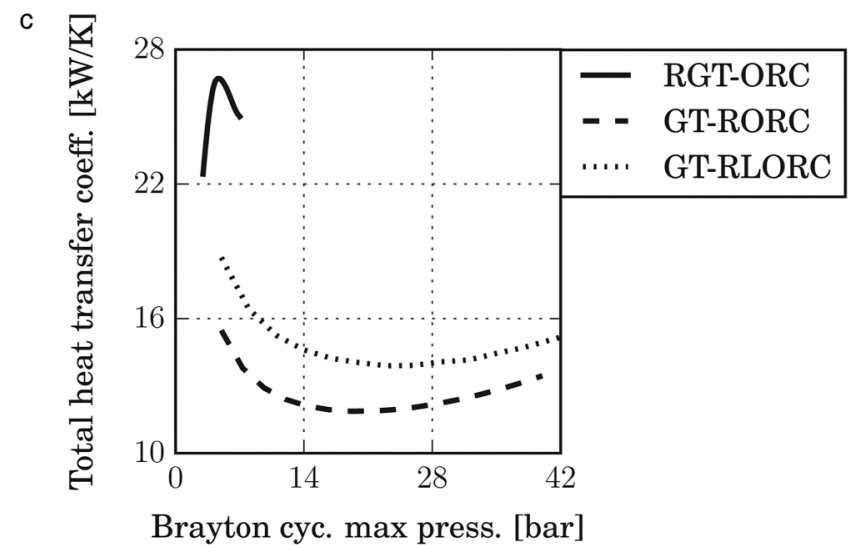

Figure 5. Thermodynamic cycle analysis: (a) net efficiency, (b) gas turbine outlet temperature, (c) exchangers heat transfer coefficient.

Figure $6 \mathrm{~b}$ and c. An optimal system configuration which mitigates this drawback would include partial recuperation in the gas turbine. In this case, it would also be possible to reduce the TIT of the gas turbine, which could also be beneficial. Other cycle configurations will be studied in future stages of this research.

Table 2. Optimal cycle specifications.

\begin{tabular}{|l|l|l|l|l|}
\hline Cycle configuration & & RGT-ORC & GT-RORC & GT-RLORC \\
\hline Net efficiency & - & 0.374 & 0.422 & 0.440 \\
\hline Net power & kW & 150.0 & 150.0 & 150.0 \\
\hline Gas turb. outlet temp. & ${ }^{\circ}$ C & 656.1 & 746.0 & 837.8 \\
\hline Br./Rn. cycle efficiency & - & $0.300 / 0.159$ & $0.287 / 0.293$ & $0.294 / 0.354$ \\
\hline Br./Rn. mass flow rate & kg/s & $0.803 / 0.353$ & $0.287 / 0.295$ & $0.231 / 0.336$ \\
\hline Br./Rn. output power & - & $120.8 / 32.4$ & $101.8 / 51.4$ & $96.1 / 57.0$ \\
\hline Br./Rn. max. pressure & bar & $4.4 / 49.1$ & $15.3 / 17.7$ & $14.2 / 22.4$ \\
\hline Br./Rn. turbine power & kW & $286.2 / 36.2$ & $239.4 / 52.4$ & $202.6 / 58.6$ \\
\hline Br./Rn. pressure ratio & - & $4.4 / 19.7$ & $15.2 / 97.1$ & $14.1 / 83.7$ \\
\hline
\end{tabular}



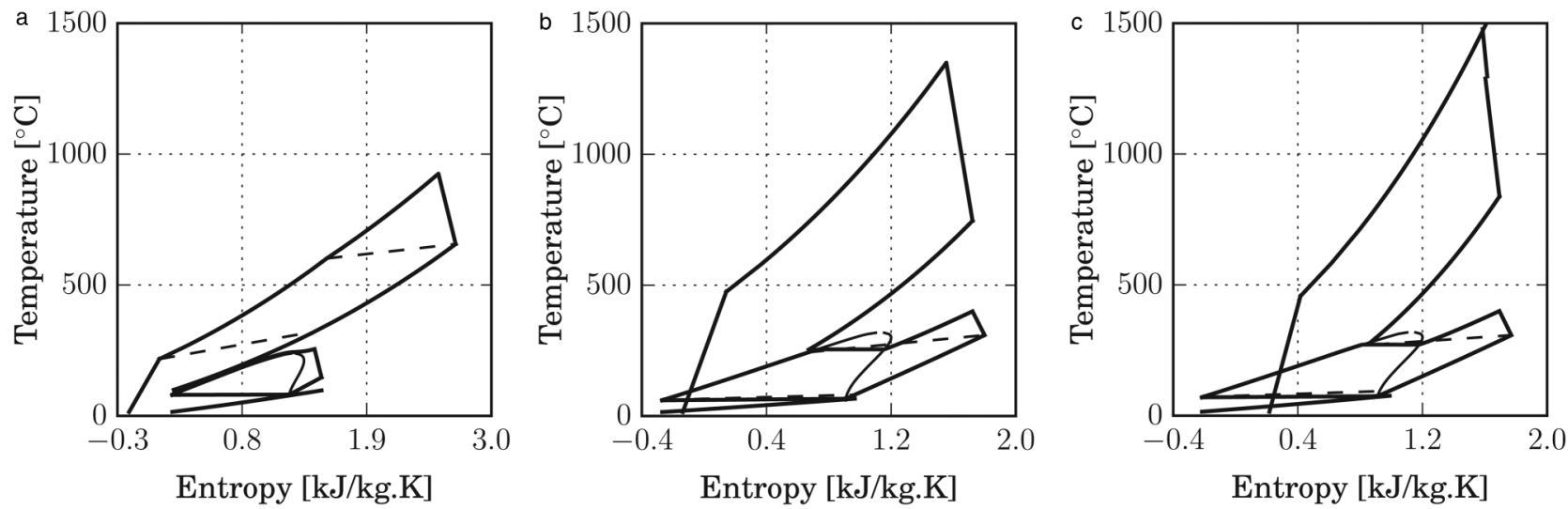

Figure 6. Temperature entropy diagrams of the optimal specifications: (a) RGT-ORC, (b) GT-RORC, (c) GT-RLORC.

The thermal efficiency of the gas turbine has the largest impact on the overall thermodynamic efficiency of the system. It follows that the optimal Brayton cycle pressure is close to that of the stand-alone $\mu \mathrm{GT}$. Thus, for the CC system featuring a gas-to-gas recuperator, the optimal pressure is 4.4 bar. The CC systems with no recuperation require a higher maximum pressure: 15.3 bar for the GT-RORC system, and 14.2 bar for the GT-RLORC system.

Due to the large gas turbine inlet temperature in the GT-RORC and GT-RLORC systems, the corresponding outlet temperature largely exceeds $650^{\circ} \mathrm{C}$ for the optimal operating conditions: $746^{\circ} \mathrm{C}$ and $838^{\circ} \mathrm{C}$, for the GTRORC and GT-RLORC configurations, respectively. Hence, these power plants require a HTHRE manufactured with special alloys or ceramic materials. On the other hand, the RGT-ORC system was designed following specifications which are representative of the state-of-art for $\mu \mathrm{GT}$ and $m \mathrm{ORC}$ turbo- generators. It can operate with a heat exchanger manufactured with conventional materials, because the turbine outlet temperature is approximately $650^{\circ} \mathrm{C}$. The RGT-ORC configuration is, from a technological point of view, the most feasible solution among those investigated.

Figure $5 \mathrm{c}$ presents the total heat transfer coefficient $U A$ as a function of the maximum pressure in the Brayton cycle. Those values, to a first approximation, are proportional to the size of the heat exchangers. The RGT-ORC System features a small $\mu \mathrm{GT}$ pressure ratio and a small specific work, hence it requires large mass flow to achieve the targeted power output. Its recuperator is characterized by large effectiveness (0.87), hence it features a large $U A$ value. Moreover, note in Figure 6a that the temperature difference between the hot and cold streams in the HRVG is small when compared against the other cases (see Figure $6 \mathrm{~b}$ and $\mathrm{c}$ for GT-RORC and GT-RLORC systems, respectively); the required heat transfer area is hence larger. It follows that the RGT-ORC system features the largest heat exchangers.

The energy carried by the gas turbine exhaust gases is larger in cycles without recuperation. As a result, the GT-RORC and GT-RLORC systems feature a bottoming cycle with larger power output. This is beneficial for the ORC turbomachinery, because it leads to larger flow passages, thus reducing scaling effects (e.g., tip clearance losses). However, the blade height of the gas turbine might be rather small, which in turn negatively affects its performance.

Two cycle configurations were selected for the design of the turbines and the heat exchangers: the RGT-ORC system, as it is the CC-configuration with the highest technological readiness; and the GT-RLORC system, because it features the best predicted efficiency.

\section{Preliminary design of gas and ORC turbines}

The combination of the low enthalpy drop in an ORC expansion, and the constraint on the volumetric flow ratio, allow to realize a single-stage radial inflow turbine for all the bottoming cycles. The same type of expander is used in the $\mu \mathrm{GT}$ of the RGT-ORC system, due to its small pressure ratio (4.4). The other $\mu \mathrm{GT}$ systems feature a four-stage axial machine, in order to limit the rotational speed to values not exceeding $150 \mathrm{krpm}$, thus easing the design of the bearing system. The selection/design of an electric generator coupled to all these turbomachines should not present a major challenge, given the current level of technology: $\mu \mathrm{GT}$ operating with rotational speeds as high as $300 \mathrm{krpm}$ have been already successfully coupled with high-speed electrical generators 
Table 3. Main constraints for the turbine optimization.

\begin{tabular}{|c|c|c|}
\hline \multicolumn{3}{|l|}{ Constraints } \\
\hline Rotational speed & krpm & $\leq 150$ \\
\hline Blade height (radial/axial) & $\mathrm{mm}$ & $\geq 2 / \geq 5$ \\
\hline Relative Mach number at rotor inlet & - & $\leq 0.9$ \\
\hline Blade tip speed & - & $\leq 700$ \\
\hline Maximum flare angle & $\circ$ & $\leq 15$ \\
\hline Minimum shaft diameter & $\mathrm{mm}$ & $\geq 10$ \\
\hline Relative Mach number at rotor inlet & - & $\leq 1.4$ \\
\hline Maximum stator angle (radial/axial) & $\circ$ & $80 / 75$ \\
\hline
\end{tabular}

(Visser et al., 2011). Table 3 itemizes the most important constraints utilized in the optimization. The work of Bahamonde et al. (2017) presents a detailed explanation of the turbine preliminary design method.

Table 4 lists the main results of the meanline design for the $\mu \mathrm{GT}$ and $m \mathrm{ORC}$ turbines of the RGT-ORC and GT-RLORC configurations. The difference in the total-to-static efficiency can be explained by means of the size parameter and the volumetric expansion ratio (Perdichizzi and Lozza, 1987; Angelino et al., 1991). The size parameter is a dimensional quantity that is proportional, for an optimized specific diameter, to the actual turbine dimensions (Angelino et al., 1991). It follows that machines with a small size parameter are generally affected by considerable tip clearance losses and Reynolds effects. Likewise, efficiency penalties from compressibility effects and large flow area variations are related to a large volumetric expansion ratio. The size parameter of the radial inflow gas turbine of the RGT-ORC is the largest, while the volumetric expansion ratio is the smallest, resulting in the best total-to-static efficiency. Conversely, the lower efficiency of the other turbines is a result of the combination between the large volumetric expansion ratio and the small size parameter. In particular, note that the cyclopentane machine seems to be strongly affected by the low size parameter, which is mostly caused by the comparatively lower power output (half the one of the toluene turbine). Finally, for the axial turbine, note that the constraints on the blade height and rotational speed prevent the stages from achieving optimal specific speed.

Table 4. Turbine specifications.

\begin{tabular}{|l|l|l|l|l|l|}
\hline Cycle configuration & \multicolumn{2}{|c|}{} & \multicolumn{2}{c|}{ RGT-ORC } & \multicolumn{2}{c|}{ GT-RLORC } \\
\hline Turbine type & - & RIT- $\mu$ GT & RIT-ORC & AXT- $\mu$ GT & RIT-ORC \\
\hline Working fluid & - & Flue gas & Cyclopentane & Flue gas & Toluene \\
\hline Power & $\mathrm{kW}$ & 303.2 & 33.8 & 195.0 & 64.0 \\
\hline Total-to-static-eff. & - & 0.911 & 0.746 & 0.843 & 0.873 \\
\hline Rotational speed & $\mathrm{krpm}$ & 57.3 & 150.0 & 150.0 & 95.5 \\
\hline Size parameter & $\mathrm{mm}$ & 54.8 & 13.6 & 25.3 & 31.7 \\
\hline Vol. exp. Ratio & - & 2.9 & 29.6 & 7.5 & 60.0 \\
\hline
\end{tabular}




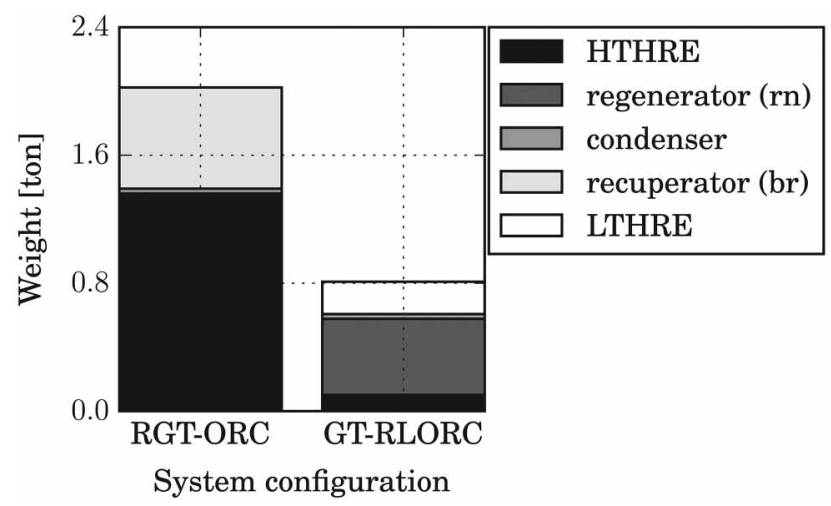

Figure 7. Heat exchangers weight for a net power output of 150 kW.

\section{Preliminary design of the heat exchangers}

Figure 7 shows the weight of the heat exchangers for the RGT-ORC and GT-RLORC systems. The contribution of the different HEX's to the overall weight of the CC unit reflects the $U A$ values corresponding to the thermodynamic cycle calculation.

The weight of the CC system is critical, for it must be added to the weight of the batteries, potentially reducing the truck payload. Due to this reason, only the lightest system, the GT-RLORC, is considered for the fuel economy analysis. The total volume of the of the heat exchanger cores of system GT-RLORC is lower than $0.5 \mathrm{~m}^{3}$. Thus, arguably, assembling the combined cycle system within the vehicle structure would not be a major challenge.

\section{Analysis of the fuel economy and estimation of the emissions}

Table 5 summarizes the parameters of the quasi-steady-state simulation with the corresponding information sources. Two types of systems were analyzed: a heavy-duty vehicle powered by a diesel reciprocating engine (CV), and a heavy-duty vehicle with a series hybrid powertrain (HEV). The total weight of both configurations is equal to the legal limit of 80000 pounds in the United States roadways. Consequently, as shown in Figure 8b, the cargo weight varies as function of the vehicle type and battery capacity. The efficiency map of the reciprocating engine has been scaled to match expected performance improvements in the upcoming years; its peak value is 0.50. Additionally, and as a first approximation, the battery energy efficiency is kept fixed at 0.95 (Ehsani et al., 2004). The CC system efficiency is slightly lower than that of the GT-RLORC prime mover, to take into account generator and transmission losses. Finally, thanks to the multi-fuel capability of gas turbines, two types of fuel have been considered for the HEV: diesel and compressed natural gas (CNG).

\section{Driving cycle}

Long-haul trucks spend $85 \%$ of their mission in cruise conditions (at $85 \mathrm{~km} / \mathrm{h}$ ), and might have an idling time between 6 and $16 \mathrm{~h}$ (Stodolsky et al., 2000; Rahman et al., 2013). A realistic mission profile has been constructed with this information, because standard driving cycles do not represent actual patterns (Zhao et al., 2013). The velocity-time profile is formed by two standard driving cycles and idling time: Urban Dynamometer Driving Schedule for Heavy-Duty Vehicles (UDDSHDV): 0-0.4 h; Heavy Heavy-Duty Diesel Truck Schedule (HHDDT): 0.4-11 h; idling: 11-17 h.

\section{Fuel economy and emissions}

Table 6 presents the results for the CV. The miles-per-gallon (mpg) are close to those obtained in a similar study (ibid.). Figure 8 shows the results of the HEV analysis for different battery capacity values. These results are expressed as percentage gain with respect to the CV benchmark.

The fuel economy has units that feature the kilograms of fuel in the denominator; it is thus affected by the corresponding LHV. For instance, in an analysis where the payload and the required mechanical energy remain constant, the vehicle employing a fuel with higher LHV will require a lower mass of fuel, thus featuring a higher fuel economy parameter.

The fuel economy gain is shown in Figure 8a. Since the results are affected by the LHV, the solution using diesel allows to provide a clear comparison between the $\mathrm{CV}$ and the HEV powertrains. The prime mover of the 
Table 5. Key parameters of the quasi-steady-state simulation.

\begin{tabular}{|c|c|c|c|}
\hline & & $\mathrm{CV}$ & HEV \\
\hline \multicolumn{4}{|l|}{ Components weight } \\
\hline Trailer $^{a}$ & ton & 2.25 & 2.25 \\
\hline Cargo $^{a}$ & ton & 30.41 & - \\
\hline Reciprocating engine ${ }^{a}$ & ton & 1.43 & 0 \\
\hline Transmission $^{a}$ & ton & 0.33 & 0.33 \\
\hline Wheel/axle $e^{a}$ & ton & 1.44 & 1.44 \\
\hline Exhaust after treatment ${ }^{a}$ & ton & 0.09 & 0 \\
\hline Electric motor/gen. + inverter ${ }^{\mathrm{b}}$ & ton & - & 0.23 \\
\hline Total weigth ${ }^{\mathrm{b}}$ & ton & 36.29 & 36.29 \\
\hline \multicolumn{4}{|l|}{ Components efficiency } \\
\hline Reciprocating engine (peak) $)^{a, c}$ & - & 0.50 & - \\
\hline Reciprocating engine (idle) ${ }^{d}$ & - & 0.11 & - \\
\hline Electric motor/gen + inverter (peak) ${ }^{a}$ & - & - & 0.94 \\
\hline Battery $^{f}$ & - & - & 0.95 \\
\hline Combined cycle & - & - & 0.44 \\
\hline CC generator + transmission & - & - & 0.96 \\
\hline \multicolumn{4}{|l|}{ Battery specifications } \\
\hline Energy density ${ }^{g}$ & kW.h/kg & - & 0.183 \\
\hline Power density ${ }^{g}$ & $\mathrm{~kW} / \mathrm{kg}$ & - & 0.817 \\
\hline Max/min state of charge & $\%$ & - & $90 / 10$ \\
\hline \multicolumn{4}{|l|}{ Other parameters } \\
\hline Engine power at idle ${ }^{g}$ & $\mathrm{~kW}$ & 4.3 & - \\
\hline Power required by auxiliaries ${ }^{g}$ & $\mathrm{~kW}$ & 1.3 & 1.3 \\
\hline Fuel & - & diesel & diesel, CNG \\
\hline CC system power & $\mathrm{kW}$ & - & 151.3 \\
\hline
\end{tabular}

References

aAlliance for Sustainable Energy, LLC (2016).

${ }^{\mathrm{b} C}$ California Department of Transportation (2017).

${ }^{\mathrm{C}}$ Gibble and Amar (2016)

${ }^{\mathrm{d}}$ Rahman et al. (2013).

eEhsani et al. (2004).

'Bower (2017).

${ }^{9}$ Stodolsky et al. (2000) 


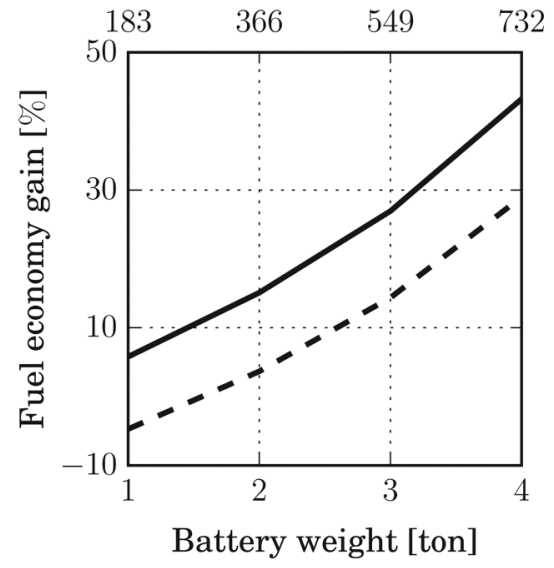

d

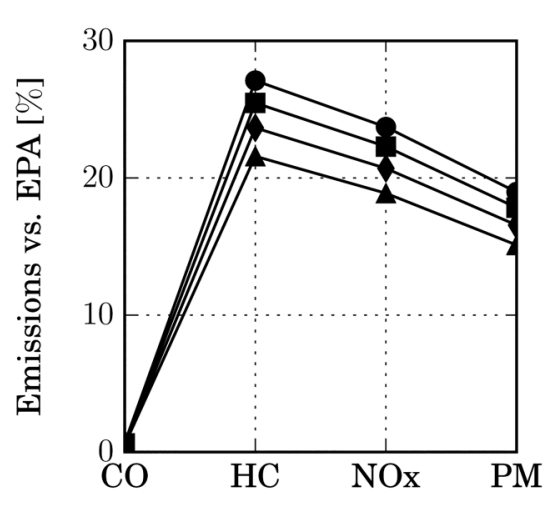

Battery capacity [kW.hr]

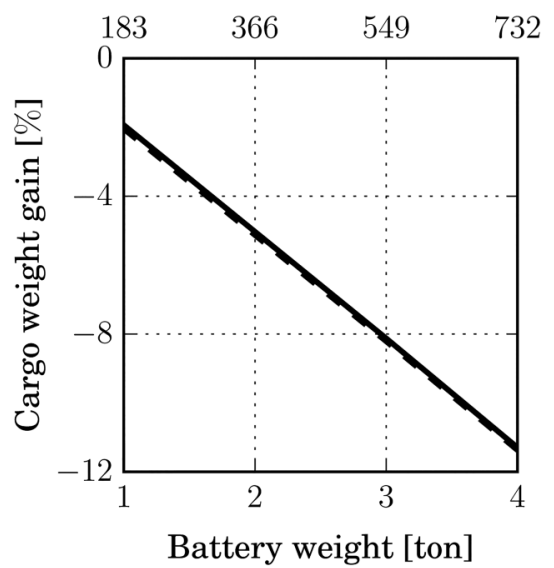

C

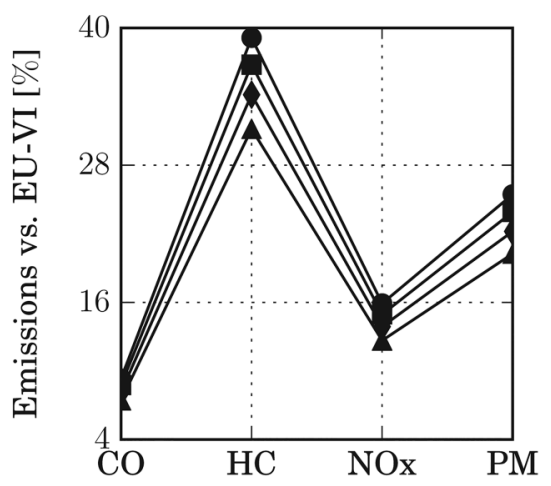

e

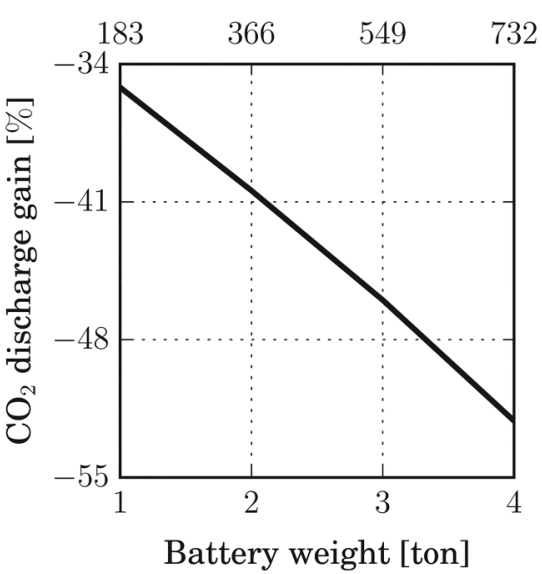

Figure 8. (a) HEV fuel economy gain and (b) cargo weight gain as a function of the battery capacity and with the CC system operating with (-) natural gas, and (- -) diesel. (c and d) Emissions compared against the Euro VI, and EPA

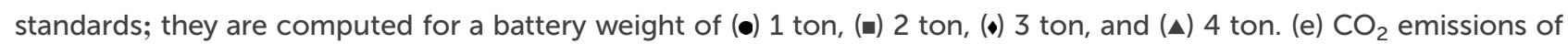
the HEV compared against the ones from the CV.

HEV powertrain is less efficient than the reciprocating engine: it has additional transmission losses, and the efficiency of the CC system is lower than that of the reciprocating engine ( 0.44 and 0.50 (peak), respectively). As a result, a HEV with a small battery will necessarily feature a negative fuel economy gain, as shown in Figure 8a. Since it is assumed that the battery is fully charged with renewable energy, it is necessary to increase the battery size to obtain a positive gain: at least $300 \mathrm{~kW} . \mathrm{hr}$, see to Figure $8 \mathrm{a}$.

However, if the fuel is CNG, the fuel economy of the HEV powertrain is better than that of the CV for all considered battery capacity values, and it also features a higher fuel economy than the system operating with diesel. This is due to the higher CNG LHV, which leads to a lower amount of consumed kg-fuel.

Observe in Figure 8a that the fuel economy can be largely improved by increasing the battery capacity. However, since the total weight cannot exceed 36.29 ton, increasing the fuel economy requires reducing the cargo weight, as shown in Figure 8b. The analysis of the corresponding economic trade-off is left for future developments. The prospect of natural gas as a fuel for long-haul trucks is positive, because its price is forecasted to be lower compared to oil in the United States (Brown, 2017). Moreover, even if the constraint on the weight is released and the payload remains constant, the fuel economy increases proportionally to the battery capacity, as it can be inferred from the trend in Figure 8a.

The analysis of the emissions was performed only for the HEV CC system operating with CNG. However, the gas turbine can also operate with diesel, and it has been proven that the corresponding emissions are dramatically lower than those from a reciprocating engine (Capstone Turbine Corp., 2010b). Figure 8c and d present the estimated HEV powertrain emissions compared to the EPA and EURO VI standards. The HEV powertrain produces emissions that are well below the regulated limits, without the need of an exhaust after-treatment unit. 
Table 6. Results of the simulation performed on a vehicle employing a diesel reciprocating engine.

\begin{tabular}{|l|l|l|l|}
\hline $\begin{array}{l}\text { Miles per gal } \\
\mathrm{mpg}\end{array}$ & $\begin{array}{l}\text { Fuel economy ton-cargo.km/ } \\
\mathrm{kg} \text {-fuel }\end{array}$ & $\begin{array}{l}\text { Payload } \\
\text { ton }\end{array}$ & $\begin{array}{l}\mathrm{CO}_{2} \text { emissions } \mathrm{kg}-\mathrm{CO}_{2} / \\
\text { ton-cargo.km }\end{array}$ \\
\hline 5.4 & 79.63 & 30.41 & $6.2 \times 10^{-3}$ \\
\hline
\end{tabular}

Finally, Figure 8e illustrates the comparison of the computed $\mathrm{CO}_{2}$ emission from the HEV vs that of the CV. A reduction of $30 \%$ with respect to the $\mathrm{CV}$ propelled by a next-generation diesel engine seems achievable.

\section{Concluding remarks}

This paper documents a preliminary assessment of a hybrid electric powertrain for heavy-duty vehicles employing a combined cycle power plant composed by a micro gas turbine and a mini organic Rankine cycle system. As test case, the performance of the proposed powertrain concept is evaluated for a long-haul truck (weight approx. 36 ton) performing a representative mission. For the $\mu \mathrm{GT}$, two fuel options were explored: diesel and compressed natural gas. As benchmark for the HEV, a conventional truck powered by a diesel reciprocating engine was considered. The relevant conclusions stemming from this work are:

- The best combined cycle system features an estimated efficiency of 0.44 . It is constituted by a non-recuperative gas turbine and a regenerative organic Rankine cycle system with an additional low temperature heat recovery exchanger. This system requires forefront technology: a $\mu \mathrm{GT}$ with film blade cooling for a maximum operating temperature of $1500^{\circ} \mathrm{C}$, and a high- temperature heat recovery exchanger manufactured with special alloys or ceramics that can operate at $840^{\circ} \mathrm{C}$.

- For a diesel-fueled hybrid powertrain, the fuel economy (ton-cargo.km/kg-fuel) can be improved by employing a battery with a capacity of at least $300 \mathrm{~kW}$.hr. The hybrid vehicle powered by natural gas showcases even more potential, as it features a higher fuel economy with ultra-low emissions.

- If compared with EPA and EURO VI standards, the hybrid powertrain fueled by natural gas produces emissions which are much lower than those prescribed, without the need of an exhaust after-treatment unit. Likewise, the $\mathrm{CO}_{2}$ discharge produced by the HEV CC powertrain fueled by natural gas is lower than one fifth that of the next-generation diesel reciprocating engine, which served as a benchmark.

In summary, this work demonstrates that the adoption of a combined cycle system in a hybrid powertrain has a considerable merit potential in terms of fuel economy and exhaust emissions. Future planned investigations will expand the analysis to cover these aspects:

- other CC system configurations;

- turbine fluid dynamic losses caused by film blade cooling;

- effect of startup and shutdown on the fuel economy and emissions;

- integrated thermodynamic cycle and heat exchanger design optimization to minimize the powertrain weight and volume.

\section{Funding sources}

This research has been supported by Bosch GmBH and the Applied and Engineering Sciences Division (TTW) of the Dutch Organization for Scientific Research (NWO), Technology Program of the Ministry of Economic Affairs, grant number 13385 .

\section{Competing interest}

Piero Colonna declares that he/she has no conflict of interest. Sebastian Bahamonde declares that he/she has no conflict of interest. Carlo De Servi declares that he/she has no conflict of interest.

\section{References}

Aharon I., and Kuperman A. (2011). Topological overview of powertrains for battery-powered vehicles with range extenders. IEEE Transactions on Power Electronics. 26 (3): 868-876. 
Alliance for Sustainable Energy, LLC. (2016) Advanced Vehicle Simulator (ADVISOR). Golden: Alliance for Sustainable Energy LLC.

Angelino G., Invernizzi C., and Macchi E. (1991) Organic working fluid optimization for space power cycles. In: Modern Research Topics in Aerospace Propulsion, 1st ed. edited by Angelino G., De Luca L., and Sirignano W. A. New York: Springer, 297-326. https://doi. org/10.1007/978-1-4612-0945-4_16

Asimptote. (2017). zTurbo, a 1D Tool for the Preliminary Design of Turbine Operating with Highly Non-ideal Fluids. Delft: Asimptote.

Aspen Technology, Inc. (2015). Exchanger Design and Rating V8.8.. Bedford: AspenTech.

Autozone.com. (2017). AutoZone Auto Parts. https://www.autozone.com/ [Accessed 01 Feb. 2018].

Bahamonde S., Pini M., De Servi C., and Colonna P. (2017). Method for the preliminary fluid dynamic design of high-temperature mini-organic rankine cycle turbines. Journal of Engineering for Gas Turbines and Power. 139 (8): 1-14. https://doi.org/10.1115/1. 4035841

Bell I., Wronski J., Quoilin S., and Lemort V. (2014). Pure and pseudo-pure fluid thermophysical property evaluation and the opensource thermophysical property library coolprop. Industrial \& Engineering Chemistry Research. 53 (6): 2498-2508. https://doi.org/10. 1021/ie4033999

Bower, G. (2017). Tesla Semi Truck Battery is How Big? https:/insideevs.com/news/332353/tesla-semi-truck-battery-is-how-big/ [Accessed 01 Feb. 2018]

Brown S. (2017). Natural gas vs. oil in U.S. transportation: Will prices confer an advantage to natural gas? Energy Policy. 110: $210-221$. https://doi.org/10.1016/j.enpol.2017.08.018

capstoneturbine.com. (2010a). Capstone Announces Launch of CARB Emissions Certified Product to Operate in Hybrid Electric Vehicles. https://www.capstoneturbine.com/news/press-releases/detail/774/ [Accessed 01 Feb. 2018].

capstoneturbine.com. (2010b). Capston Turbine C30 CNG Microturbine Certified to CARB 2010 Requirement for On-Road Heavy-Duty Diesel Engines for Urban Bus. https://www.capstoneturbine.com/news/press-releases/detail/2114/ [Accessed 01 Feb. 2018].

Chang Y., and Wang C. (1997). A generalized heat transfer correlation for louver fin geometry. International Journal of Heat and Mass Transfer. 40 (3): 533-544. https://doi.org/10.1016/0017-9310(96)00116-0

Chang Y., Chang W., Li M., and Wang C. (2000). A generalized friction correlation for louver fin geometry. International Journal of Heat and Mass Transfer. 23 (21-22): 2237-2243. https://doi.org/10.1016/S0017-9310(99)00289-6

Chrysler Corporation, Technical Information Engineering office (1979). History of Chrysler Corporation Gas Turbine Vehicles. https:// turbinecar.com/misc/History.pdf [Accessed 01 Feb. 2018].

Colonna P., van der Stelt T. P., and Guardone A. (2019). FluidProp (Version 3.1): A program for the estimation of thermophysical properties of fluids, A computer program since 2004.

Date A. (2011.) Analytic Combustion: With Thermodynamics, Chemical Kinetics and Mass Transfer. Cambridge: Cambridge University Press.

De Paepe W., Montero M., Bram S., Parente A., and Contino F. (2014). Experimental characterization of a T100 micro gas turbine converted to full humid air operation. Energy Procedia. 61: 2083-2088. https://doi.org/10.1016/j.egypro.2014.12.081

dot.ca.gov. (2018). Legal Truck Access. http://www.dot.ca.gov/trafficops/trucks/weight.html [Accessed 01 Feb. 2018].

ec.europa.eu. (2017). Reducing $\mathrm{CO}_{2}$ emissions from Heavy-Duty Vehicles. https://ec.europa.eu/clima/policies/transport/vehicles/heavy_en [Accessed 01 Feb. 2018].

Ehsani M., Gao Y., and Emadi A. (2004.) Modern Electric, Hybrid Electric, and Fuel Cell Vehicles. Fundamentals, Theory, and Design. 2nd ed. Boca Raton: CRC Press LLC.

freightliner.com. (2017). Natural Gas Freightliner. https://freightliner.com/trucks/natural-gas/ [Accessed 01 Feb. 2018]

Gibble J., and Amar P. (2016). Volvo SuperTruck Powertrain Technologies for Efficiency Improvement.

Gnielinski G. (1976). New equation for heat and mass transfer in turbulent pipe and channel flow. International Chemical Engineering. 16 (2): 359-368

Goodarzi A. (2017). USHybrid: Integrated Electric, Fuel Cell and Hybrid Powertrain Components Powering Clean Mobility.

Guzzella L., and Ambühl A. (2005). QuasiStatic Simulation Toolbox. Zurich: Institute for Dynamic Systems and Control.

Guzzella L., and Sciarretta A. (2013.) Vehicle Propulsion Systems. Introduction to Modeling and Optimization. Berlin: Springer-Verlag.

Harinck J., Pasquale D., Pecnik R., van Buitenen J., and Colonna P. (2013). Performance improvement of a radial ORC turbine by means of automated design. Proceedings of the Institution of Mechanical Engineers, Part A: Journal of Power and Energy. 227 (6): 637-645.

Head A. J., De Servi C., Casati E., Pini M. and Colonna P. (2016). Preliminary design of the ORCHID: A facility for studying nonideal compressible fluid dynamics and testing ORC expanders. In: ASME Turbo Expo, 2016, number GT2016-56103, pages 1-14. ASME, June 13-17 2016. New York: ASME.

Hesselgreaves J. (2001.) Compact Heat Exchangers - Selection, Design and Operation. Amsterdam: Elsevier.

Hoekman S., and Robbins C. (2012). Review of the effects of biodiesel on NOx emissions. Fuel Processing Technology. 96: 237-249. https://doi.org/10.1016/j.fuproc.2011.12.036

Holmberg K., Andersson P., Nylund N., Mäkela K., and Erdemir A. (2014). Global energy consumption due to friction in trucks and buses. Tribology International. 78: 94-114. https://doi.org/10.1016/j.triboint.2014.05.004

Horlock J. (2003.) Advanced Gas Turbine Cycles. Amsterdam: Elsevier.

Invernizzi C., Iora P., and Silva P. (2007). Bottoming micro-Rankine cycles for micro-gas turbines. Applied Thermal Engineering. 27 (1): 100-110. https://doi.org/10.1016/j.applthermaleng.2006.05.003

Invernizzi C., Iora P., Manzolini G., and Lasala S. (2017). Thermal stability of n-pentane, cyclo-pentane and toluene as working fluids in organic Rankine engines. Applied Thermal Engineering. 121: 172-179. https://doi.org/10.1016/j.applthermaleng.2017.04.038

Kays W., and London A. (1998.) Compact Heat Exchangers. 3rd ed. Malabar: Krieger.

Lockart R., and Martinelli R. (1949). Proposed correlation of data for isothermal two-phase two-component flow in a pipe. Chemical Engineering Progress. 45: 39-48.

Lu P., Fu T., Garg S., and Nowakowski G. (1987). Boiler Stack Gas Heat Recovery. [online] Port Hueneme: Naval Civil Engineering Laboratory. https://apps.dtic.mil/docs/citations/ADA187419 [Accessed 01 Feb. 2018]. 
Massardo A., McDonald C., and Korakianitis T. (2002). Microturbine/fuel-cell coupling for high-efficiency electrical-power generation. Journal of Engineering for Gas Turbines and Power. 124 (1): 110-116. https://doi.org/10.1115/1.1398552

McDonald C., and Rodgers C. (2008). Small recuperated ceramic microturbine demonstrator concept. Applied Thermal Engineering. 28 (1): 60-74. https://doi.org/10.1016/j.applthermaleng.2007.01.020

Perdichizzi A., and Lozza G. (1987). Design criteria and efficiency prediction for radial inflow turbines. In: Proceedings of the ASME 1987 International Gas Turbine Conference and Exhibition. Volume 1: Turbomachinery. Anaheim, California, USA. May 31-June 4, 1987. V001T01A086. New York: ASME.

Pini M., Persico G., Casati E., and Dossena V. (2013). Preliminary design of a centrifugal turbine for organic Rankine cycle applications. Journal of Engineering for Gas Turbines and Power. 135 (4): 1-9. https://doi.org/10.1115/1.4023122

Pini M., De Servi C., Burigana M., Bahamonde S., Rubino A., et al. (2017). Fluid dynamic design and characterization of a mini-ORC turbine for laboratory experiments. Energy Procedia. 129: 1141-1148. https://doi.org/10.1016/j.egypro.2017.09.186

Python 2.7. (2017). Wilmington: Python Software Foundation.

Rahman S., Masjuki H., Kalam M., Abedin M., Sanjid A., and Sajjad A. (2013). Impact of idling on fuel consumption and exhaust emissions and available idle-reduction technologies for diesel vehicles-A review. Energy Conversion and Management. 74: 171-182. https://doi.org/10.1016/j.enconman.2013.05.019

Reşitoğlu A., Altinişik K., and Keskin A. (2015). The pollutant emissions from diesel-engine vehicles and exhaust aftertreatment systems. Clean Technology Environmental Policy. 17: 15-27. https://doi.org/10.1007/s10098-014-0793-9

Reynolds W., and Colonna P. (2018.) Thermodynamics. Fundamentals and Engineering Applications. Cambridge: Cambridge University Press.

saftbatteries.com. (2005). High Energy Lithium-Ion Cell. https://www.saftbatteries.com/120-Techno/20-10_Lithium_system.asp [Accessed 01 Feb. 2018].

Shah R., and Sekulić D. (2003.) Fundamentals of Heat Exchanger Design. New Jersey: John Wiley \& Sons, Inc.

Sharpe, B. and Muncrief, R. (2015). Literature Review: Real-world Fuel Consumption of Heavy-duty Vehicles in the United States, China, and the European Union. [online] Washington: International Council on Clean Transportation, p. 5. https://theicct.org/publications/ literature-review-real-world-fuel-consumption-heavy-duty-vehicles-united-states-china [Accessed 01 Feb. 2018].

Shi L., Shu G., Tian H., and Deng S. (2018). A review of modified Organic Rankine cycles (ORCs) for internal combustion engine waste heat recovery (ICE-WHR). Renewable and Sustainable Energy Reviews. 92: 95-110. https://doi.org/10.1016/j.rser.2018.04.023

Spiga M., and Dall'Olio R. (1995). Friction factor and Nusselt number in flat tubes with rounded edges. International Journal of Heat and Fluid Flow. 16: 307-310. https://doi.org/10.1016/0142-727x(95)00031-k

Stodolsky F., Gaines L. and Vyas A. (2000). Analysis of Technology Options to Reduce the Fuel Consumption of Idling Trucks. Lemont: Argonne National Laboratory, 22. https://trid.trb.org/view/666964 [Accessed 01 Feb. 2018].

Taguchi H., Komori K., Kido O., Nishiwaki F., and Nishiyama Y. (2017). Micro gas turbine system. EP 3203052 B1.

Taylor M. (1990.) Plate-Fin Heat Exchangers: Guide to their Specification and Use. Oxfordshire: HTFS for the Plate-Fin Study Group.

The Mathworks, Inc. (2017). Simulink-Simulation and Model-Based Design.

UQM Technologies, Inc. (2017). futuregreen-electronic.com. UQM PowerPhase HD220. https://www.futuregreen-electronic.com/ products/uqm-powerphase-hd220-1 [Accessed 01 Feb. 2018].

Vick M., Young T., Kelly M., Tuttle S., and Hinnant K. (2016). A simple recuperated ceramic microturbine: design concept, cycle analysis, and recuperator component prototype tests. In: ASME Turbo Expo. 8. 1-14. https://doi.org/10.1115/gt2016-57780

Visser W., Shakariyants S., and Oostveen M. (2011). Development of a $3 \mathrm{~kW}$ Microturbine for CHP Applications. Journal of Engineering for Gas Turbines and Power. 133 (4): 1-8. https://doi.org/10.1115/1.4002156

Wrightspeed Powertrains. (2017). Wrightspeed Technology. https://www.wrightspeed.com/technology [Accessed 01 Feb. 2018].

Yadav M., Giri S., and Momale V. (2017). Sizing analysis of louvered fin flat tube compact heat exchanger by genetic algorithm. Applied Thermal Engineering. 125: 1426-1436. https://doi.org/10.1016/j.applthermaleng.2017.07.119

Zhao, H., Burke A., and Miller M. (2013). Analysis of Class 8 truck technologies for their fuel savings and economics. Transportation Research Part D, 23, pp. 55-63. https://doi.org/10.1016/j.trd.2013.04.004 